\title{
Self-care difficulties of adolescents with type 1 diabetes
}

\section{Dificuldades no autocuidado dos adolescentes com diabetes mellitus tipo 1 Dificultades en el autocuidado de adolescentes con diabetes mellitus tipo 1}

Marília Costa Flora*; Manuel Gonçalves Henriques Gameiro**

\begin{abstract}
Background: Type 1 diabetes (T1D) is a chronic disease that is increasingly prevalent in adolescence. Intervention in selfcare is essential for disease management.

Objectives: To identify the self-care difficulties of adolescents with T1D. Analyze the association between the self-care difficulties of adolescents with T1D and age and gender.

Methodology: Descriptive-analytical and cross-sectional study. The sample was composed of 51 adolescents aged between 12 and 18 years being followed-up in district hospitals of the center region of Portugal. We developed a questionnaire on the adolescents' difficulties based on a model of self-care roles, consisting of 18 items distributed by 4 dimensions: Health maintenance; Disease management; Diagnosis, treatment and Medication in T1D; and participation in health services.

Results: Most adolescents (96.1\%) found it easy to manage self-care, $29.4 \%$ of them found it difficult to adjust insulin to blood glucose levels, and $17.6 \%$ of them found it difficult to recognize the importance of glycated hemoglobin.

Conclusion: Adolescents showed significant levels of difficulty in insulin adjustment and interpretation of glycated hemoglobin.
\end{abstract}

Keywords: teenager; type 1 diabetes; self-care; nursing

\section{Resumo}

Enquadramento: A diabetes mellitus tipo 1 (DM1) é uma doença cada vez mais prevalente na adolescência. Intervir no autocuidado é determinante para o seu controlo.

Objetivos: Determinar as dificuldades no autocuidado dos adolescentes com DM1. Analisar a relação das dificuldades no autocuidado dos adolescentes com DM1 com a idade e o género. Metodologia: Estudo descritivo-analítico e transversal. Participaram 51 adolescentes entre os 12 e os 18 anos, seguidos em hospitais distritais da zona centro de Portugal. Foi construído um questionário de dificuldades adaptado de um modelo de papéis de autocuidado, constituído por 18 itens distribuídos por 4 dimensões: Manutenção da saúde; Controlo da doença; Diagnóstico, tratamento e Medicação na DM1 e, participação nos serviços de saúde.

Resultados: Referem ter pouca dificuldade em gerir o autocuidado (96,1\%), bastante dificuldade no ajuste de insulina mediante a avaliação de glicemia capilar (29,4\%), bastante dificuldade em reconhecer a importância da hemoglobina glicosilada (17,6\%).

Conclusão: Os adolescentes revelaram níveis de dificuldade relevantes no ajuste de insulina e na compreensão da hemoglobina glicosilada.

Palavras-chave: adolescente; diabetes mellitus tipo 1; autocuidado; enfermagem

\footnotetext{
*MSc., RN, Specialist in Child Health and Pediatric Nursing, Ph.D. student in Nursing, Nursing School of Coimbra, 3046-851, Coimbra, Portugal [liaflora@esenfc.pt]. Address for correspondence: Rua $1 .^{\circ}$ de Maio, lote $58 \mathrm{~b}, 2^{\circ}{ }^{\circ} \mathrm{D}$, Edf. Gardénia, Chã, 3080-847, Figueira da Foz, Portugal. Contribution to the article: literature search, data collection with questionnaire administration, data treatment, analysis and discussion, article writing.

** Ph.D., Specialist in Child Health and Pediatric Nursing. Coordinating Professor, Nursing School of Coimbra Coimbra, 3046-851, Coimbra, Portugal [mgameiro@esenfc.pt]. Contribution to the article: supervisor of the master's thesis, data treatment, analysis and discussion, guidance for article writing.
}

\section{Resumen}

Marco contextual: La diabetes mellitus tipo 1 (DM1) es una enfermedad que cada vez tiene más prevalencia en la adolescencia. Por ello, intervenir en el autocuidado es esencial para controlarla.

Objetivos: Determinar las dificultades en el autocuidado de los adolescentes con DM1. Analizar la relación de las dificultades en el autocuidado de los adolescentes con DM1 con la edad y el género.

Metodología: Estudio descriptivo, analítico y transversal. Participaron 51 adolescentes con edades comprendidas entre los 12 y 18 años a los que se les realizó un seguimiento en hospitales de la zona centro de Portugal. Se elaboró un cuestionario de dificultades adaptado de un modelo de autocuidado que consta de 18 ítems distribuidos en 4 dimensiones: mantenimiento de la salud; control de la enfermedad; diagnóstico, tratamiento y medicación en la DM1, y participación en los servicios de salud. Resultados: El 96,1\% indicó que tiene pocas dificultades para gestionar la enfermedad, el 29,4\% que tiene bastantes dificultades para ajustar la insulina de acuerdo con la evaluación de la glucemia capilar, y el 17,6\% bastantes dificultades para reconocer la importancia de la glucohemoglobina.

Conclusión: Los adolescentes indicaron que tienen niveles de dificultad relevantes en el ajuste de la insulina y en la interpretación de la glucohemoglobina.

Palabras clave: adolescente; diabetes mellitus tipo 1; autocuidado; enfermería

Received for publication: 07.08 .16

Accepted for publication: 25.11.16 


\section{Introduction}

Type 1 diabetes (T1D) is an autoimmune disease caused by the destruction of pancreatic beta cells in the islets of Langerhans, with absolute insulin deficiency, requiring insulin therapy to ensure survival (Hockenberry \& Wilkenstein, 2006). In Portugal, in 2014, the incidence of diabetes was 17.5\% (261 new cases) per 100,000 inhabitants aged between 0 and 14 years. In 2000 , the incidence was $9.5 \%$, corresponding to 160 new cases. These results follow the international trend of increase of T1D at increasingly younger ages (Correia et al., 2015). The long-term complications resulting from inadequate disease management can lead to an increased mortality and risk for micro and macrovascular complications.

Adolescence is a stage of human development characterized by profound physical, psychological, and social changes that begin during puberty and end with adulthood. Adolescence is a period of rapid physical, cognitive, social, and emotional development (Hockenberry \& Wilkenstein, 2006). The World Health Organization defines adolescence as the period between 10 and 19 years of age: early adolescence as the period between the ages of 10 and 14 years, and adolescence itself as the period between the ages of 15 and 19 years (World Health Organization, 2011). Adherence to self-care is difficult for most diabetic patients. However, it is more difficult for adolescents (Morris, Boyle \& McMahon as cited in Winter 2013). The obstacles to self-care in diabetes relate to the level of development, family interaction, and social pressures, which add up to the insulin resistance brought on by developmental physiology (Borus \& Laffel as cited in Winter 2013).

Chronic illness in adolescence is characterized by its slow and gradual progression with the need for long-term treatment and an impact on the physical and intellectual development (Perrin as cited in Pilger \& Abreu, 2007). The variation in blood glucose levels results in tissue damage and microvascular complications such as retinopathy and nephropathy, which are highly influenced by glycemic control (Miculis, Mascarenhas, Boguszewski, \& Campos, 2010).

Diabetes is a risk factor for depression, anxiety, and eating disorders such as bulimia and anorexia. Adolescents with diabetes are three times more likely to become depressed than the general population
(Leite, Zanim, Granzotto, Heupa, \& Lamounier, 2008). The adequate management of diabetes has an impact on the reduction of healthcare-related costs, loss of income, loss of productivity, and loss of economic development opportunities (Correia et al., 2015).

This study aimed to identify the self-care difficulties of adolescents with T1D. To this end, we designed an inventory of difficulties, based on Santos' model of self-care roles (as cited in Filho, Rodrigues, \& Santos, 2008). For data collection, we applied a questionnaire to adolescents with T1D who attended the diabetology consultation of the District Hospital of Figueira da Foz EPE (HDFF.EPE) and the endocrinology consultation of the Hospital Center of Baixo Vouga EPE (CHBV. EPE), as well as to adolescents who were members of an association of diabetics (AD) located in the central region of Portugal. We conducted a descriptive and analytical study in a population of adolescents with T1D, with the following objectives: to identify the self-care difficulties of adolescents with T1D, and to analyze the association between the self-care difficulties of adolescents with T1D and age and gender.

\section{Background}

T1D "is an autoimmune disease characterized by the progressive loss of pancreatic beta cells culminating in the interruption of insulin production and, consequently, severe metabolic imbalance" (Miculis et al. 2010, p. 276). The first manifestations of this autoimmune disease appear when the person is exposed to a triggering event, such as a viral infection, bacteria, or chemical agent (Hockenberry \& Wilkenstein, 2006). The treatment consists of several measures that, when combined, allow for the normalization of blood glucose levels with an impact on the patient's well-being and quality of life. These measures include pharmacological and non-pharmacological interventions: the former refer to insulin therapy, and the latter focus on diet and physical activity (Correia et al., 2015). T1D requires an autonomous and responsible attitude of adolescents and their families in disease management.

Adolescence is associated with a process of change and therefore with major physical and emotional vulnerability, which often makes adolescents resistant to change. The typical characteristics of this age group, such as rebellion, experimentation, and 
attempt to control their own destiny, are an obstacle to therapeutic management and, therefore, to self-care (Fialho, Dias, Nascimento, Mota, \& Pereira, 2011). The difficulties arise throughout the process of adaptation, but start to be perceived as adolescents become involved in disease management. The treatment is complex and involves a change of habits, the results are not immediate, and there is no perspective of cure. With regard to self-care, it is "a human regulatory function individuals must, with deliberation, perform themselves or have performed for them to maintain life, health, development, and well-being" (Tomey \& Alligood, as cited in Queirós, Vidinha, \& Filho, 2014, p. 159). As regards self-care conditioning factors, Ataíde and Damasceno (2010, p. 518) describe the following factors as interfering with disease management: "age, life experiences, culture, gender, lifestyles, education, and beliefs". They also highlighted environmental and socio-economic factors and issues in the health system as elements that interfere with the process.

Self-care in diabetes management includes: administration of insulin, monitoring of blood glucose, maintaining records of insulin administration, managing hypoglycemia and hyperglycemia, complying with meal plans, and exercising regularly (Chien, Larson, Nakamura, \& Lin, 2007). Self-care deviation can result from characteristics of the disease and treatment, namely the fact that it is a chronic illness without immediate discomfort or evident risk. It can also compromise clinical decisions, to the extent that the prescription of insulin and its assessment depend on adolescents and families' attitudes towards the disease (Anderson et al. as cited in Lewin et al., 2009). With regard to the difficulties, adolescents have greater difficulty in accepting the disease when compared to children. Children depend directly on the parents or guardians' care, while adolescents should assume responsibility for their own care. For adolescents, the major difficulties are related to the uncertainty about the disease course, the need to comply with a meal plan, and the adaptation to a routine of social obligations, such attending school, parties, and activities that must be compatible with their medical appointments (Minanni, Ferreira, Sant'Anna, \& Coates, 2010). The provision of support to adolescents with T1D and their families is essential for disease management, minimizing its medium- and long-term complications. This support begins at the disease onset and should continue throughout life in a gradual and evolving process at the different developmental phases of the person with T1D.

\section{Research questions}

What are the self-care difficulties of adolescents with T1D in relation to disease management?

Are the self-care difficulties associated with the age and gender of adolescents with T1D?

\section{Methodology}

For the analysis of content validity, the instrument items were assessed by experts in the area of diabetology, namely a pediatrician, a diabetology nurse, and an endocrinologist. Adjustments were made based on their suggestions. We also examined the dispersion of answers, by calculating the mean scores ranging from 0 to 1 and the standard deviation for the answers to each item. We found that all questions had very close standard deviation values, which shows consistency.

The sample for this study consisted of 51 adolescents with T1D. The adolescents were selected taking into account the following criteria: diagnosis of T1D, not hospitalized, aged between 12 and 19 years. This age range was selected due to the adolescents' maturity level and their potential to perform self-care roles autonomously.

Before the questionnaire application, we requested the written authorization of the board of directors of the HDFF, EPE and the CHBV, EPE, and also an AD. The study began after the favorable opinion from the Ethics Committee of each institution. This study used a quantitative, descriptive-analytical, and cross-sectional research design. According to the proposed model of analysis, our core variable was the difficulties in self-care roles. In relation to other variables, we considered the adolescents' demographic characteristics of age and gender.

\section{Population and Sample: type of sample}

Of the total sample, 32 adolescents (62.7\%) were recruited at the endocrinology consultation of the 
CHBV, EPE; 11 adolescents (21.6\%) during the activities of an $\mathrm{AD}$, followed-up in consultations of hospitals in the central region; and eight adolescents $(15.7 \%)$ at the diabetology consultation of the HDFF, EPE. This was an accidental sample, since the adolescents integrated the study as they attended the consultations/AD meetings, and only when the researcher was present. The sample was selected at different times between September 2012 and February 2013. In relation to gender, the sample is balanced: 25 girls (49\%) and 26 boys (51\%). With regard to age, the mean age of the sample was 15 years $(S D=2.07 ; M d=15)$. Age groups are equally distributed, with a similar number of participants per age range. However, there is a higher prevalence of adolescents aged between 12 and 14 years. The age group between 12 and 14 years was composed of 21 adolescents (41.2\%), followed by the age group between 15 and 17 years, with 19 adolescents (37.3\%), and the age group of adolescents aged over 17 years, with 11 adolescents (21.6\%). All respondents lived in the central region of Portugal.

\section{Instrument}

We developed a demographic, sociocultural, and clinical questionnaire, including questions relevant to sample characterization, and an inventory of difficulties in self-care roles, based on Santos' model of self-care roles (as cited in Filho et al., 2008). According to the authors, self-care roles for patients with T1D are divided into the following dimensions: Health maintenance, which consists of sustaining a better quality of life through the performance of self-care actions, effectively enabling a healthy condition; Prevention of acute and chronic complications of T1D, which consists of preventing complications in order to maintain disease under control; Diagnosis, treatment and medication in T1D, which consists of recognizing the signs and symptoms of hyperglycemia and hypoglycemia and therapeutic adjustment; and Active participation in health services, which consists of using the available health support structures.

Although the model was used as the basis for the development of an inventory of Difficulties in Self-Care Roles, some aspects listed in this model, which was applied to a Brazilian sample, were not completely adjusted to the reality of the Portuguese population. Thus, some items had to be adapted. In the dimension Health maintenance, the following aspects were not considered: maintain scheduled immunizations, and practice religious activities. In the dimension Disease management, instead of the item related to Measurement of glycated hemoglobin (HbA1c), which is a responsibility of the health team that monitors the adolescents and not a responsibility of the adolescent or other adults, we included the item Recognize the importance of (HbA1c). Additionally, we included the item administer of insulin since the authors did not mention it but we consider this aspect to be essential for an effective diabetes management. The authors also considered the dimension Prevention of acute and chronic complications. However, we believe that, from a conceptual perspective, the various aspects covered by this dimension do not relate to disease complications, rather to disease management, which is why we changed the name of the original version to Disease management. Nevertheless, there is a direct association between the non-fulfilment of these selfcare roles and the increased risk of T1D complications. In view of the above, the adapted version of the instrument was composed of 18 questions divided into four dimensions: Health maintenance, Disease management, Diagnosis, treatment and Medication in DM1, and Participation in health services. In turn, each dimension is composed of multiple items, as shown in Table 1. To complete this instrument, the adolescents had to mark with a cross $(X)$ the answer that best described their situation on a 4-point Likerttype scale (1 to 4): "no difficulty" (1), "somewhat difficult" (2) "difficult" (3) "very difficult" (4). 
Table 1

Inventory of difficulties in self-care roles

\begin{tabular}{ll}
\hline & Control weight \\
& Have a balanced diet \\
Health maintenance & Avoid smoking \\
& Avoid drinking alcohol \\
& Perform leisure activities on a regular basis \\
& Reduce stress \\
& Practice regular physical activity \\
\hline & Measure blood glucose \\
& Recognize the importance of glycated hemoglobin (HbA1c) \\
& Control blood glucose \\
Disease management & Administer insulin \\
\hline \multirow{3}{*}{ Diagnosis, treatment and medication } & Identify signs and symptoms of hypoglycemia \\
in DM1 & Intervene in case of hypoglycemia \\
& Identify signs and symptoms of hyperglycemia \\
& Intervene in case of hyperglycemia \\
& Adjust insulin to blood glucose levels \\
\hline \multirow{2}{*}{ Participation in health services } & Access to the health service of reference \\
& Contact with the team of reference \\
\hline
\end{tabular}

In relation to this instrument, the overall difficulty was assessed by calculating the mean scores of all items. The score of difficulty was also assessed for each dimension.

Reliability of the inventory of difficulties in self-care roles

We analyzed the internal consistency of each dimension and of the total instrument, by calculating

Table 2
Cronbach's alpha coefficients and the corrected item-total correlations, as shown in Table 2. The inventory of difficulties in self-care roles obtained a value of .695 , which indicated an acceptable internal consistency. With regard to the responsibility dimensions, the lowest internal consistency value found was .505 in the dimension Diagnosis, treatment, and medication in T1D.

Internal consistency of the dimensions of difficulties in self-care roles $(n=51)$

\begin{tabular}{|c|c|c|c|}
\hline Dimensions & Items & $\begin{array}{l}\text { Corrected item-total } \\
\text { correlation }\end{array}$ & $\begin{array}{c}\text { Alpha of the dimension if } \\
\text { item deleted }\end{array}$ \\
\hline Health maintenance & $\begin{array}{l}\text { Control weight } \\
\text { Have a balanced diet } \\
\text { Avoid smoking } \\
\text { Avoid drinking alcohol } \\
\text { Perform leisure activities on a regular basis } \\
\text { Reduce stress } \\
\text { Practice regular physical activity } \\
\text { (Cronbach's alpha of .628) }\end{array}$ & $\begin{array}{l}.263 \\
.359 \\
.219 \\
.341 \\
.325 \\
.528 \\
.368\end{array}$ & $\begin{array}{l}.613 \\
.586 \\
.630 \\
.592 \\
.600 \\
.523 \\
.581\end{array}$ \\
\hline Disease management & $\begin{array}{l}\text { Assess blood glucose } \\
\text { Control blood glucose } \\
\text { (Cronbach's alpha of .560) }\end{array}$ & $\begin{array}{l}.391 \\
.391\end{array}$ & $\begin{array}{l}- \\
-\end{array}$ \\
\hline $\begin{array}{l}\text { Recognize the impor- } \\
\text { tance of HbA1c } \\
\text { Administer insulin }\end{array}$ & $\begin{array}{l}1 \\
1\end{array}$ & $\begin{array}{l}- \\
-\end{array}$ & $\begin{array}{l}- \\
-\end{array}$ \\
\hline
\end{tabular}




\begin{tabular}{llll}
\hline Diagnosis, treatment and & Identify signs and symptoms of hypoglycemia & .256 & .484 \\
medication in DM1 & Intervene in case of hypoglycemia & .333 & .541 \\
& $\begin{array}{l}\text { Identify signs and symptoms of hyperglycemia } \\
\text { Intervene in case of hyperglycemia } \\
\text { (Cronbach's alpha of.505) }\end{array}$ & .538 & .146 \\
& -163 & .545 \\
\hline $\begin{array}{l}\text { Adjust insulin to blood } \\
\text { glucose levels }\end{array}$ & 1 & - & - \\
& & & - \\
\hline $\begin{array}{l}\text { Participation in health } \\
\text { services }\end{array}$ & $\begin{array}{l}\text { Access to the health service of reference } \\
\text { Contact with the team of reference } \\
\text { (Cronbach's alpha of.510) }\end{array}$ & .345 & - \\
\hline
\end{tabular}

The items Recognize the importance of HbA1c, Administer insulin, and Adjust insulin to blood glucose levels were analyzed separately since they had a very low item-total correlation of $<.20$.

\section{Data collection}

The instrument was applied in dates previously scheduled with the nursing team of each institution and with the person responsible for the $\mathrm{AD}$. Before the application of the instrument, the adolescents and their parents/guardians were explained the nature of the study, as well as its objective and purpose. Data anonymity was ensured. The instrument was applied after the adolescents and their parents/guardians had signed an informed consent form. The participants completed the questionnaire individually for approximately 15 minutes.

\section{Results}

The adolescents were grouped by levels of difficulty, considering the following intervals: (1-2) easy, (2-3) difficult, and (3-4) very difficult, as shown in Table 3. With regard to the difficulties in self-care roles, most adolescents reported that managing self-care roles was easy (96.1\%). This result is similar in the different dimensions of difficulties, except for the dimension Participation in health services.

We also observed that the adolescents had more difficulties in the dimension Participation in health services (70.6\% in level 3-4). These data may be due to the fact that parents or legal guardians are mainly the ones who contact with the health services. This dimension was followed by the dimension Recognize the importance of HbA1c (11.8\% found it difficult, and 17.6\% found it very difficult). It should also be noted that $29.4 \%$ of adolescents experienced a high level of difficulty (level 2-3) in the dimension Adjust insulin to blood glucose levels.

Table 3

Distribution of the sample subjects by levels of difficulty in the self-care roles and summary measures

\begin{tabular}{|c|c|c|c|c|c|c|c|c|c|}
\hline \multirow[t]{2}{*}{ Difficulty in self-care roles } & \multicolumn{2}{|c|}{$\begin{array}{l}\text { Easy } \\
(1-2)\end{array}$} & \multicolumn{2}{|c|}{$\begin{array}{c}\text { Difficult } \\
(2-3)\end{array}$} & \multicolumn{2}{|c|}{$\begin{array}{l}\text { Very difficult } \\
(3-4)\end{array}$} & \multirow[t]{2}{*}{$\mathrm{Md}$} & \multirow[t]{2}{*}{$\bar{\chi}$} & \multirow[t]{2}{*}{$S D$} \\
\hline & $n$ & $\%$ & $n$ & $\%$ & $n$ & $\%$ & & & \\
\hline Health maintenance & 45 & 88.2 & 6 & 1.8 & - & 0.0 & 1.29 & 1.41 & 0.35 \\
\hline Disease management & 44 & 86.3 & 5 & 9.8 & 2 & 3.9 & 1.00 & 1.37 & 0.51 \\
\hline Recognize the importance of HbA1c & 36 & 70.6 & 9 & 17.6 & 6 & 11.8 & 1.00 & 1.45 & 0.81 \\
\hline Administer insulin & 43 & 84.3 & 6 & 11.8 & 2 & 3.9 & 1.00 & 1.20 & 0.49 \\
\hline Diagnosis, treatment and medication in DM1 & 47 & 92.2 & 4 & 7.8 & - & 0.0 & 1.25 & 1.26 & 0.31 \\
\hline Adjust insulin to blood glucose levels & 34 & 68.6 & 15 & 29.4 & 1 & 2.0 & 1.00 & 1.36 & 0.60 \\
\hline Participation in health services & -- & 0.0 & 15 & 29.4 & 36 & 70.6 & 2.0 & 1.9 & 0.60 \\
\hline Overall difficulties & 49 & 96.1 & 2 & 3.9 & -- & 0.0 & 1.33 & 1.33 & 0.23 \\
\hline
\end{tabular}


Association between the difficulties in self-care roles and age

With regard to the difficulties in self-care roles, an additional analysis was performed to analyze the possible correlation between the difficulties in self-care roles and age. Spearman's correlation coefficients between the total, the various dimensions of difficulties, and age were calculated. Table 4 shows

Table 4

Difficulties in self-care roles and age $(n=51)$ a statistically significant negative correlation between age and Recognize the importance of HbA1c (rs $=-.355$, and $p=.010$ ), which suggests that older adolescents tend to have less difficulty in recognizing the difficulties in self-care roles. We found a positive association between age and Health maintenance on the threshold of significance ( $r s=.273$ and $p=.053$ ).

\begin{tabular}{lcc}
\hline Difficulties in self-care roles & & Age \\
\hline Health maintenance & $r s=$ & .273 \\
Disease management & $p=$ & .053 \\
Recognize the importance of HbA1c & $r s=$ & .122 \\
Administer insulin & $p=$ & .395 \\
& $r s=$ & $-.355^{*}$ \\
Diagnosis, treatment and medication in DM1 & $p=$ & .010 \\
Participation in health services & $r s=$ & -.044 \\
Adjust insulin to blood glucose levels & $p=$ & .758 \\
Overall difficulties & $r s=$ & .024 \\
& $p=$ & .865 \\
\end{tabular}

Note. $r s=$ Spearman's correlation.

*Significant $p<.05$.

Association between the difficulties in self-care roles and gender

We performed an additional statistical analysis in order to examine the association between the difficulties in self-care roles and gender (Table 5). To this end, we applied Mann-Whitney U tests and found a statistically significant correlation between gender and the dimension Adjust insulin to blood glucose levels ( $Z$ $=-2.632$ and $p=.008$ ), indicating that adolescents reported more difficulties in this dimension.

Table 5

Difficulties in self-care roles and gender

\begin{tabular}{lccccc}
\hline & & \multicolumn{2}{c}{ Gender } & Mann-Whitney Test \\
\cline { 3 - 5 } & & Female & Male & & \\
& & $(n=25$ & $(n=26)$ & $\mathrm{Z}$ & $p$ \\
\hline \multirow{3}{*}{ Health maintenance } & $\mathrm{Md}$ & 1.29 & 1.29 & -.133 & .894 \\
& $\bar{\chi}$ & 1.40 & 1.43 & & \\
\hline \multirow{3}{*}{ Disease management } & $S D$ & .30 & .40 & & .480 \\
& $\mathrm{Md}$ & 1.50 & 1.00 & -.706 & \\
\hline
\end{tabular}




\begin{tabular}{|c|c|c|c|c|c|}
\hline \multirow{3}{*}{ Recognize the importance of $\mathrm{HbA1c}$} & $\mathrm{Md}$ & 1.00 & 1.00 & -.705 & .481 \\
\hline & $\bar{\chi}$ & 1.40 & 1.50 & & \\
\hline & $S D$ & .82 & .81 & & \\
\hline \multirow{3}{*}{ Administer insulin } & $\mathrm{Md}$ & 1.00 & 1.00 & -.060 & .952 \\
\hline & $\bar{\chi}$ & 1.20 & 1.19 & & \\
\hline & $S D$ & .50 & .49 & & \\
\hline \multirow{3}{*}{$\begin{array}{l}\text { Diagnosis, treatment and medication } \\
\text { in DM1 }\end{array}$} & $\mathrm{Md}$ & 1.25 & 1.25 & -.010 & .992 \\
\hline & $\bar{\chi}$ & 1.27 & 1.26 & & \\
\hline & $S D$ & .32 & .30 & & \\
\hline \multirow{3}{*}{ Adjust insulin to blood glucose levels } & $\mathrm{Md}$ & 1.50 & 1.00 & -2.632 & $.008^{* *}$ \\
\hline & $\bar{\chi}$ & 1.58 & 1.15 & & \\
\hline & $S D$ & .72 & .37 & & \\
\hline \multirow{3}{*}{ Participation in health services } & $\mathrm{Md}$ & 1.00 & 1.00 & -.460 & .645 \\
\hline & $\bar{\chi}$ & 1.16 & 1.12 & & \\
\hline & $S D$ & .31 & .26 & & \\
\hline \multirow{3}{*}{ Overall difficulties } & $\mathrm{Md}$ & 1.33 & 1.28 & -.569 & .569 \\
\hline & $\bar{\chi}$ & 1.34 & 1.32 & & \\
\hline & $S D$ & .21 & .25 & & \\
\hline
\end{tabular}

Note. *Significant $p<.05 ;$ **Highly significant $p<.01$

\section{Discussion}

Self-care in diabetes requires adopting strategies for metabolic control, and focuses on the practice of physical activity, diet, and insulin therapy with the purpose of normalizing HbA1c. Self-care management was identified as an important strategy for improving diabetic patients' metabolic control (Morris et al. as cited in Stewart, Emslie, Klein, Haus, \& White, 2005). The instrument developed in this study aimed to operationalize the multiple difficulties in self-care roles. Most adolescents found it easy to manage self-care (level 1-2) on a 4-point scale.

The authors of a study on how adolescents managed diabetes and activities of daily living identified the following difficulties: fear and uncertainty about the disease course, the reeducation of eating habits, and the restriction in fulfilling social and group obligations due to frequent consultations (Santos \& Enumo 2003). With regard to the dimensions of difficulties, adolescents reported having more difficulty (level 3-4) in the dimensions Participation in health services, and Recognize the importance of HbAlc. In the dimension Adjust insulin to blood glucose levels, $29.4 \%$ of adolescents found it difficult (level 2-3). It is important to work with adolescents on these aspects, particularly the latter aspects since disease management depends directly on the adolescents' ability to adjust insulin to blood glucose levels.
Nascimento et al. (2011) described the following self-care management difficulties: pain in blood glucose measurement, and fear of insulin administration. These aspects relate to the pain experienced during the procedure and may explain the adolescents' difficulty in managing insulin administration. The use of insulin pumps and continuous blood glucose monitoring devices minimizes the impact of the pain associated with the use of pen needles.

At school, the lack of a proper and private space for insulin administration is one of the aspects that can lead to resistance to disease management. We found that age is negatively correlated with the difficulty Recognize the importance of HbA1c, i.e., the older the patient, the fewer self-care difficulties in this dimension.

The authors of a study with adolescents aged between 9 and 14 years with diabetes, analyzed how they behaved in case of blood glucose fluctuations, and concluded that, although older diabetic adolescents had greater problem-solving skills, they are conditioned by the acceptance of behaviors by their peers. According to this study, adolescents experience dilemmas related to diabetes management because they tend to behave according to their peers (Wysocki et al., 2008).

In turn, gender is correlated with the dimension Adjust insulin to blood glucose levels. With regard to self-care difficulties, Zanetti and Mendes (2001) concluded that the most common difficulties 
reported by mothers of adolescents with diabetes are related to diet, school and physical activities, family's behavior, and relationship with the health care team. They also mentioned a major difficulty in adapting to the new diet and limiting the intake of carbohydrates in festive days.

Throughout the study, the results were influenced by some limitations, namely the delay in receiving the institutions' authorization to conduct the study. In addition, the sample size was significantly limited by the fact that most consultations took place on a quarterly basis.

\section{Conclusion}

T1D is a chronic disease with a significant impact on the lives of adolescents and their families. This study allowed identifying difficulties in disease management among adolescents with T1D.

In general, 96.1\% of adolescents found it easy to manage self-care roles. In terms of the dimensions of difficulty, we observed that $11.8 \%$ and $17.6 \%$ of the adolescents found it difficult and very difficult, respectively, to Recognize the importance of HbA1c. In addition, 29.4\% of adolescents found it difficult to Adjust insulin to blood glucose levels.

Nursing intervention strategies should strengthen organizational skills, and introduce best practice models in diabetes management following pre-established guidelines. Interventions should take into account sociocultural, family, and personal variables, and focus on educating and guiding patients on self-monitoring and self-management. Self-monitoring is achieved through the repeated assessment of blood glucose levels, whereas self-management corresponds to the adolescents' ability to adapt to fluctuations in blood glucose levels through insulin therapy, diet, and exercise.

There is an urgent need to analyze the needs of adolescents with T1D and their families, as well as to identify organized support structures that allow the continuity of pediatric community care, in close connection with hospital care. After the adaptation and assessment of its psychometric properties, the instrument developed in this study proved to be valid and reliable. We believe that its replication in different settings requires further improvements.

\section{References}

Ataíde, M. B., \& Damasceno, M. M. (2010). Fatores que interferem na adesão ao autocuidado em diabetes. Revista Enfermagem UERI, 14(4), 518-523. Retrieved from http://www.facenf. uerj.br/v14n4/v14n4a05.pdf

Chien, S. C., Larson, E., Nakamura, N., \& Lin, S. J. (2007). Self-care problems of adolescents with type 1 diabetes in Southern Taiwan. Journal Of Pediatric Nursing, 22(5), 404-409. doi:10.1016/j.pedn.2006.05.011

Correia, L., Boavida, J. M., Almeida, J. P., Anselmo, J., Ayala, M.,Cardoso, S.,Costa, A. L.,...Raposo, J. (2015). Diabetes: Factos e números 2014: Relatório anual do observatório nacional da diabetes. Retrieved from https://www.dgs. pt/estatisticasde-saude/estatisticas-de-saude/publicacoes/ diabetes-factose-numeros-7-edicao.aspx

Fialho, F. A., Dias, I. M., Nascimento, L., Motta, P. N., \& Pereira, S. G. (2011). Crianças e adolescentes com diabetes mellitus: Implicações para a enfermagem. Revista Baiana de Enfermagem, 25(2), 145-154. doi:10.18471/rbe.v25i2.4820

Filho, C. V., Rodrigues, W. H., \& Santos, R. B. (2008). Papéis de autocuidado: Subsídio para a enfermagem diante das reações emocionais dos portadores de diabetes mellitus. Escola Anna Nery Revista de Enfermagem, 12(1), 125-129. Retrieved from http://www.scielo.br/scielo.php?script=sci_arttext\&pid $=$ S1414-81452008000100019

Hockenberry, M. J., \& Wilkenstein (2006). A criança com disfunção endócrina. M. J. Hockenberry (Ed.), Wong - fundamentos de enfermagem pediátrica (pp.1063-1095). Rio de Janeiro, Brasil: Elsevier.

Leite, S. A., Zanim, L. M., Granzotto, P. C., Heupa, S., \& Lamounier, R. N. (2008). Pontos básicos de um programa de educação ao paciente com diabetes mellitus tipo 1. Arquivo Brasileiro Endocrinologia e Metabolismo, 52(2), 233-242. doi:10.1590/ S0004-27302008000200010

Lewin, A. B., LaGreca, A. M., Geffken, G. R., Williams, L. B., Duke, D. C., Storch, E. A., \& Silverstein, J. H. (2009). Validity and reliability of an adolescent and parent rating scale of type 1 diabetes adherence behaviors: The self-care inventory (SCI). Jounal Of Pediatric Psychology, 34(9), 1000-1007. doi:10.1093/jpepsy/jsp032

Miculis, C. P., Mascarenhas, L. P., Boguszewski, M. C., \& Campos, W. (2010). Atividade física na criança com diabetes tipo 1. Jornal de Pediatria, 86(4), 271-278. doi:10.1590/S002175572010000400005

Minanni, C. A., Ferreira, A. B., Sant'Anna, M. J., \& Coates, V. (2010). Abordagem integral do adolescente diabético. Revista Adolescencia e Saude, 7(1), 45-52. Retrieved from http:// www.adolescenciaesaude.com/detalhe artigo.asp?id=181

Nascimento, L. C., Amaral, M. J., Sparapani, V. C., Fonseca, L. M., Rodrigues, M. D., \& Dupas, G. (2011). Diabetes mellitus tipo 1: Evidências da literatura para seu manejo adequado, na perspectiva de crianças. Revista da Escola de Enfermagem da USP, 45(3), 764-769. doi:10.1590/S0080-62342011000300031 
Pilger, C., \& Abreu, I. (2007). Diabetes mellitus na infância: Repercussões no cotidiano da criança e de sua família. Cogitare Enfermagem, 12(3), 494-501.doi:10.5380/ ce.v12i4.10076

Queirós, P. J.,Vidinha, T. S., \& Filho, A. J. (2014). Autocuidado: O contributo teórico de Orem para a disciplina e profissão de enfermagem. Revista de Enfermagem Referência, 4(3), 157-164. Retrieved from http://www.scielo.mec.pt/pdf/ref/ vserIVn3/serIVn3a18.pdf

Santos, J. R., \& Enumo, S. R. (2003). Adolescentes com diabetes mellitus tipo 1: Seu cotidiano e enfrentamento da doença. Psicologia: Reflexão e Crítica, 16(2), 411-425. Retrieved from http://www.scielo.br/pdf/prc/v16n2/a21v16n2.pdf

Stewart, S. M., Emslie, G. J., Klein, D., Haus, S., \& White, P. (2005). Self-care and glycemic control in adolescents with type I diabetes. Children's Health Care, 34(3), 235-244. doi: http:// dx.doi.org/10.1207/s15326888chc3403_5
Winter, C. (2013). The correlates of the health-related quality of life of paediatric patients with diabetes type 1 (Master's thesis) Faculty of Behavioural Sciences

University of Twente.

World Health Organization. (2011). Adolescent health. Geneva, Switzerland: Author.

Wysocki, T., Iannotti, R., Weissberg-Benchell, J., Laffel, L., Hood, K., Anderson, B., \& Chen, R. (2008). Diabetes problem solving by youths with type 1 diabetes and their caregivers: Measurement, validation, and longitudinal associations with glycemic control. Journal of Pediatric Psychology, 33(8), 875-884. doi:10.1093/jpepsy/jsn024

Zanetti, M. L., \& Mendes, I. A. (2001). Análise das dificuldades relacionadas às atividades diárias de crianças e adolescentes com diabetes mellitus tipo 1: Depoimento de mães. Revista Latino-Americana de Enfermagem, 9(6), 25-30. doi:10.1590/ S0104-11692001000600005 